\title{
原著論文＼cjkstart総合的な学習の時間における環境教育展開の 意義と課題
}

\author{
藤岡 達也 \\ 上越教育大学大学院学校教育研究科
Development of Environmental Education from the Viewpoint of Period of Integrated Study \\ Tatsuya FUJIOKA \\ Graduate School of Education, Joetsu University of Education \\ (受理日 2007 年 11 月 17 日)
}

In this paper, I discuss the significances of Period of Integrated Study for the practice of Environmental Education in Japanese schools. Lately the importance of ESD (Education for Sustainable Development) concluding the contexts of environmental education has been emphasized. But it is not so easy for Japanese school teachers to practice these subjects on school curriculum. From 2002, the Period of Integrated Study has started for the purpose of "zest for living" in the national Curriculum. Actually, the hours of lessons such as science or mathematics have been decreased, so it has occurred the possibility of inadequate learning. But it is clear that only acquirement of knowledge or skills are not enough for students for their futures.

For the active development of Period of Integrated Study, the construction of partnerships between schools and regions will be more necessary. In Japan, we can see the typical practices in rural area. There are many kinds of problems in school or rural area. But we can look forward to the possibility of solutions for problems by the effective practice of Period of Integrated Study.

For the new development of school education, the roles of teacher will be more important. For that, training or In-service training of teachers will be more necessary.

Key words: Environmental Education, Period of Integrated Study, School Education, ESD (Education for Sustainable Development)

\section{1 はじめに}

1991年に中・高等学校編、1992年に小学校編 が発行された『環境教育指導資料』は 2007 年 3 月 にまず小学校編が改訂された。この間、環境教育 を取り巻く教育環境そのものが大きく変わってき た。例えば、教育界の動向として、教育基本法が 改正され、これを受け「学校教育法等の一部を改 正する法律案」などいわゆる教育関連三法が改正
され、2007年度中には学習指導要領も改訂され ようとしている。

その一方で、依然として、学校教育をめぐる山 積みの問題や地域の様々な課題など、解決の糸口 が見えないことも多い。さらに学校教育には、国 際化や高度情報通信化への対応などの新たな取り 組みも迫られている。本稿では、環境教育の推進 によって、これからの学校教育や地域の課題に向 けてのアプローチが可能となる点を模索したい。

\footnotetext{
問い合わせ先 干943-8512 上越市山屋敷町 1

E-mail: fujioka@juen.ac.jp
} 
ところで、総合的な学習の時間の創設は教科教 育の内容が重視されていたり、枠組みが固定され ていたりした従来の教育課程の中で、環境教育の 新たな展開と学校教育での位置づけの確立が期待 された。本稿で述べるように、総合的な学習の時 間は、環境教育および「持続可能な開発のための 教育」(Education for Sustainable Development: 以後、 ESD と略記）のねらいや目的と同じところ がある。ところが、総合的な学習の時間が始まっ た時期とほほ同じく、学力低下の問題が論議さ れ、この時間の在り方そのものについての問題点 が指摘された。今後、改正が予定されている学校 教育法施行規則では、総合的な学習の時間の授業 数の削減が予定されており、環境教育の観点から も改めてこの時間を再考する必要がある。

当然ながら環境教育は学校教育だけでなく、家 庭や地域での取り組みも重要である。しかし、環 境教育に限らず、子どもの時からの継続的な教育 の重要性や体系的・組織的な教育を実践する上 で、学校教育の持つ意義は大きい。たた、学校教 育そのものが時代の変化に対応して変わりつつあ ることも踏まえておく必要がある。

学校での環境教育を構築するためには、今日、 必要とされる知識やスキルの習得だけでなく、長 期的な視野の中で、学校教育ではどのような人材 の育成の観点が不可欠か、そのためにどのような 教育活動が必要かが論じられており、これらを無 視することはできない。その中で、今後、環境教 育として、取り扱うべき具体的な教育内容、教育 方法等を、特に「総合的な学習の時間」とのかか わりを意識しながら検討する必要がある。

本稿では、このような教育界の変䩗期とも言え る時期に刊行された『環境教育指導資料（小学校 編)』(国立教育政策研究所 2007 ; 以後、「指導資 料」（2007）と略記）を踏まえ、総合的な学習の 時間に焦点をあて、学校教育における環境教育の 現状と課題および今後に期待される展開について 論じる。特に地域と学校とのパートナーシップの 構築など地域を主体とした取り組みについて、学 校や教員に期待される新たな役割や在り方を展望 したい。このことによって逆に現代の日本のおか
れた状況と課題についても新たな視座を築くこと が期待できるからである。

\section{2 環境教育、ESDのねらいと総合的な学習の 時間の問題}

\section{2-1 環境教育、ESD、総合的な学習の時間の関 連性}

国際的に注目されつつあり、従来の学校教育の 中での「環境教育」を含めたESD と「総合的な 学習の時間」のねらいには共通点が認められる。 このことは、「指導資料」(2007) や「国連持続可 能な開発のための教育の 10 年」関係省庁連絡会 議（2006）（以下「わが国における『国連持続可 能な開発のための教育の 10 年』実施計画」とする) にも明確に記されている。

例えば、上の「わが国における『国連持続可能 な開発のための教育の 10 年』実施計画」とする) の中で、「3． $\mathrm{ESD}$ 実施の指針（3）教育の内容」 として「小中高等学校においては、各教科等や 総合的な学習の時間など学校教育活動全体を通 して、ESDに関して学習することが重要になる。 特に総合的な学習の時間では、各教科等で学んだ ことをいかして、自ら調べたり、考えをまとめ発 表したりするなど、ESDに関する学習を一層深 めることが可能である。」(p.6-7) と記されてい る。つまり、ESDの学習の深化には、知識だけ でなく、総合的な学習の時間で重視されている体 験型の学習や問題解決型の学習が重要であること が示されている。

また、「このような学習を通じて、地域づくり に参画する態度を育成することが大切である。」 （p.7）と記述されているように、学校での総合的 な学習の時間を通して、学習者が地域づくりに参 画することの重要性が指摘されていることにも注 目したい。実際、総合的な学習の時間の学習活動 では、小学校で地域や学校の特色に応じた課題が 92.5\%に達している（文部科学省 2004）。また、 横断的・総合的な課題の中で、具体的な活動とし て環境に関する課題を実施している学校が $75.3 \%$ に及んでいる。児童・生徒がどのような活動を通 して、地域づくりに参画する態度を育成すること 
が可能であるかは、これからの環境教育推進のた めに重要な意味をもつと考えられるので、後に詳 しく論じたい。

さらに、実施計画「 $3 . \mathrm{ESD}$ 実施の指針 (5) 育みたい力」では、「小中高等学校の総合的な学 習の時間は、体験を通じて学校等で学んだ知識の 定着、思考力、判断力、表現力、問題解決能力の 育成、調べ方やまとめ方、発表の仕方などを身に つけさせることを目指して行われており、ESD において重視すべき点と重なるため、その充実が 必要。」（p.8）と表されている。つまり、ESDを 具体的に実践するためには、「総合的な学習の時 間」が不可欠であるとも読み取ることができる。

これからの時代に育成が望まれる資質・能力に ついて、同様なことは先の「指導資料」(2007) の中で「総合的な学習の時間では、問題解決的な 学習活動が展開される中で、自ら課題を見付ける 課題発見の力、追究や調査のための計画を立案す る力、収集した情報を整理し処理する力などの学 習方法に関する能力の育成が期待できる。また、 他者や社会とのかかわる力や自分で考え行動する 力なども育成される。このような総合的な学習の 時間で育成される能力は、環境教育で重視する 能力や態度と多くの部分で重なりが見られる。」 （p.41）と記されている。従って、ここでも環境 教育を実践することができる力は、総合的な学習 の時間で培うことが期待できる力と同じであると 捉えられている。

また、「小学校学習指導要領」(文部科学省 2004）では、「総合的な学習の時間においては、 次のようなねらいをもって指導を行うものとす る。（1）自ら課題を見付け、自ら学び、自ら考え、 主体的に判断し、よりよく問題を解決する資質や 能力を育てること。(2) 学び方やものの考え方を 身に付け、問題の解決や探究活動に主体的、創造 的に取り組む態度を育て、自己の生き方を考える ことができるようにすること。（3）各教科、道徳 及び特別活動で身に付けた知識や技能等を相互に 関連付け、学習や生活において生かし、それらが 総合的に働くようにすること。」(p.3) と記載さ れている。「指導資料」(2007) では、これをその
まま引用して、「こうした考え方は、環境教育の ねらいである『1環境に対する豊かな感受性 (2) 環境に関する見方や考え方の育成 (3)環境に働き かける実践力の育成』と共通する点が多く、深く 関係している。(p.41) と述べている。

しかし、この表現は抽象的であり、具体的にど のような学習や教育活動を想定しているのかが明 確でない。そのため、「第 3 章 環境教育に関す る実践事例」が設定され、「7 総合的な学習の 時間における実践事例」として、（1）子どもの興 味・関心に応じた学習展開、(2) 勤労・生産体験 を取り入れた学習展開、（3）都市型環境における 学習展開、(4) 環境問題に取り組む学習展開がそ れぞれ挙げられている。地域の特色に応じた活動 事例も多く記されているが、必ずしも全国各地の 学校で実践できるものとは言えないし、担当教員 の力量にも大きく影響される。

つまり、これらを実現するための教育システム の構築も不可欠となる。環境教育に関する教員の 高い専門性が必要であるが、教員の資質・能力を 向上させる機会が保障されなくてはならない。例 えば、上述の指導資料の実践事例では、指導計画 が 27 時間から 40 時間になっている。これらの絞 られた項目の範囲内で児童の関心を比較的長期に わたって継続させ、活動の成果を明確にするのは 容易ではない。また、上に記されたような環境教 育のねらいに適ったものかどうかについて、活動 を進める中で修正していく指導力も重要である。 このように、教員の資質・能力の向上のためには 研修の在り方も再構築する必要があり、これは後 に論じる。

さらに、いかに一人の教員の力量が優れていた としても、一つ一つの活動における全児童の意識 や行動を把握し、評価することは容易ではない。 確かに、上の指導資料の中で実践事例においても 活動ごとに教師の指導と支援とともに、評価の観 点も記載はされている。これは、前回の「環境教 育指導資料 (小学校編)」(文部省 2002) に記さ れた実践事例と大きく異なる点の一つである。総 合的な学習の時間では、教科のような評定はされ ないとはいえ、いわゆる「指導と評価の一体化」 
の観点は不可欠である。この場合も指導でなく支 援という表現がされることもあるが、総合的な学 習の時間の指導方法や指導体制は学習指導要領の 総則の中でも記されており、指導の観点を明確に したり、児童の変容などの活動評価を行ったりす ることは重要である。ただ、グループ活動が多い 中で、児童一人一人に応じた指導を行い、それら を的確に評価することは必ずしも容易ではない。

\section{2-2 総合的な学習の時間の問題点を踏まえた今 後の展開}

さて、学校教育の中で、環境教育が体系的に取 り扱われる機会として、教科横断という性格をも つ総合的な学習の時間の設定には、当初から大き な期待がされてきた。実際、この時間を活用して、 従来の教科の枠組みの中では取り扱われにくかっ た内容や活動も可能となり、現在でも成果が報告 されている。

しかし、一方では、総合的な学習の時間はその ねらいに結びつく活動とみなされず、他の教科等 の授業時間数の減少とも重なって、児童・生徒の 学力低下にも繋がりかねないという問題点も指摘 されている。そこで、ここでは、少し、総合的な 学習の時間の課題について考察したい。

総合的な学習の時間の中では、国際理解、情 報、環境、福祉・健康などの横断的・総合的な 課題や地域や学校の特色に応じた課題などが学習 活動の例として挙げられている。しかし、環境教 育は環境だけを取り扱うのではなく、他の例に挙 げられた内容とも深い関連性を持っている。つま り、環境問題への取り組みには、必然的に福祉や 健康についての認識、異文化理解などの国際理解 教育とも関わりが深く、これらを無視しての実践 は考えられないことが多い。そして、それらをつ なげるための知識・スキルの習得も重要な意味が ある。例えば、国際理解での英語教育、情報での コンピュータ教育等がカリキュラム上に明記され る可能性としての総合的な学習の時間への期待で ある。学校教育では、保護者や地域に対して目的 や活動の成果が明確であることから、そちらが重 視される傾向も否定できない。

さて、総合的な学習の時間は 2002 年に、まず
小・中学校から実施され、翌2003年には高等学 校でも始まった。そのねらいについては先に記し たとおりであり、「生きる力の育成」との整合性 からは大きな矛盾がないように見える。しかし、 始まるとほほ同時に学力低下の懸念が表面化し、 総合的な学習の時間に対する評価もこの影響を受 け始めた。2003年10月には「初等中等教育にお ける当面の教育課程及び指導の充実・改善方策に ついて」（文部科学省 2007）が答申され、総合 的な学習の時間の在り方が再考されることになっ た。

その流れの中で 2003 年 12 月には、学習指導要 領が一部改訂された。この改正時で特徴的なこと がいくつか挙げられる。最も大きい点は、それま で学習指導要領に記載されている内容は、取り扱 いとして標準であったものが、最低基準を記した ものと捉えられるようになったことである。つま り、条件付きではあるが、学習指導要領を超えた 内容を取り扱うことも可能になったことである。 また、発展的な学習が可能になるなど、個に応 じた指導の必要性が明確になったことも特色であ る。しかし、ゆとり教育の修正とも言えるこの改 定の中で、総合的な学習の時間は一層充実される ことが明確にされた。

さらに、総合的な学習の時間の取り扱いとして は、「4 各学校においては、学校における全教育 活動との関連の下に、目標及び内容、育てようと する資質や能力及び態度、学習活動、指導方法や 指導体制、学習の評価などを示す総合的な学習の 時間の全体計画を作成するものとする。」(文部科 学省 2004, p.3）と計画作成の重要性が記された。 また、総合的な学習の時間の学習活動を行うに当 たって、配慮するものとして、新たに 5 項目が挙 げられた。その中で「学校図書館の活用、他の学 校との連携、公民館、図書館、博物館等との社 会教育施設や社会教育関係団体等の各種団体との 連携、地域の教材や学習環境の積極的な活用など について工夫すること」(文部科学省 2004, p.4) が記されている。従来から、環境教育の実践では、 このような学校内外の人材・施設の活用がなされ てきた。しかし、学習内容の中で明確に学習指導 
要領に取り上げて記載されたのは画期的なことと 言える。

文部科学省のWebページ上に開設された「新 しい学習指導要領」（文部科学省 2007）を見る と、教育課程の枠組みの修正が進められる方向に あり、国語力や理数教育の充実、授業時数の見直 しが避けられそうもない。しかし、一方で「体験」 や「課題解決」をキーワードとした学習や生活の 基盤づくりなどが重視されており、自ら学び自ら 考える力の育成もこれまでどおりに期待されてい る。つまり、次期学習指導要領でも、2003年 12 月の改訂を継続するものと考えられ、基礎・基本 の徹底とともに、探究型の学習も求められている と予想される。知識・スキルの習得型の学習と探 究型の学習とのバランスを持った活動が期待され るが、具体的な内容や方法については学校や教員 に委ねられることになる。

環境教育の実践には、学校・教員側としても地 域の課題を的確に把握、理解し、児童・生徒の発 達に応じて教材化を図る必要がある。さらに、学 校によっては異文化理解や国際理解などの動向を 無視するわけにはいかないところもある。そのた め、小学校での英語教育の在り方が論議されるよ うにもなっている。その一方で、地域を主題とし た環境教育を総合的な学習の時間で実践していく ことを通して、地域の活性化の可能性が求められ る場合もある。

\section{3 これからの環境教育として期待される 教育内容と教育方法}

\section{3-1 これからの教育内容の課題と背景}

ここでは、環境教育や総合的な学習の時間の中 で取り扱われる教育内容について、教科外、教科 内の課題やその背景を考察する。学校での環境教 育の推進にあたっては、各教科、道徳、特別活動、 総合的な学習の時間での具体的な展開を検討する 必要があり、これらを反映して「指導資料」(2007) でも、それぞれの教科等での環境教育の指導につ いて、多くのページが割かれている。特に、教科 としては、社会科、理科、生活科、家庭科、体育 科の中では、教科のねらいと環境教育のねらい、
教科の学習内容と環境教育、指導上の留意事項の 3 項目が記されている。しかし、本稿では、教科 の枠を越えた観点から、学校教育の課題を考察し たい。

まず、教科外の取り組みとして、2001年に改 正された「学校教育法」（文部科学省 2001）に明 記されたように、小学校での社会奉仕・自然体験 活動のような体験的な学習が重視されつつある。 これらの活動は子ども達の成長に関わることが期 待されているが、新しい体験活動ではない。むし ろ、高度経済成長期以前の日本では、学校教育の 中で意図的に取り組まれなくても、自然体験は当 然ながら社会体験についても、日常生活の一部で あった。第一次産業に従事する人口割合が高い時 代は、親や親戚、近所の人達が働く姿を直接目に することが多かった。また、家業の手伝い等も日 常であり、これは、農林業、漁業等で生計を立て ている地方だけでなく、都市部においても生産業 や販売業などでは職場と家庭が密着し、家族等が 関わる中で、子ども達の体験や実感があった。し かし、近年では、子ども達は「労働」のような 社会体験から離れて育つことも多い。さらに、核 家族が一般化した近年では、環境教育の一環とし て、世代間交流のように地域の年配者と子ども達 との交流が進められるケースも見られる（大阪 府 2002)。

今日の課題は、学校教育の中でこれらの活動を 取り入れざるを得ないところがある。このこと は、「指導資料」（2007）においても、指導上の留 意事項として、「(4) 家庭や地域社会等との連携 で進める環境教育」の中で、学校、家庭及び地域 社会の三者の教育機能が十分発揮される必要性と して述べられている。かつては、上述した自然体 験、社会体験、世代間交流等は、学校教育では取 り扱う必然性はなかった。地域や家庭で学習して いたことを組織的、意図的に取り扱う必要がある ところに現在の学校や教員にとまどいが生じてい るのも事実である。

加えて、フリーターやニートの増加する問題に ついて、小学校段階からのキャリア教育の必要性 が論じられているが、これらの解決にも学校や教 
員だけでは限界がある。地域の人材や資源の活用 が不可欠であり、ここにも教員のコーディネータ 力という新たな能力が必要となる。しかし、単独 の学校や教員個人のネットワークだけでは限界が ある。そこで、教育委員会が人材バンクの設定 や大学・民間企業等とのコーディネータの役割を 果たすなど新たなパートナーシップの構築（藤岡 2003）も生じている。

次に教科の課題と総合的な学習の時間等との関 連性を考察する。「指導資料」（2007）の中では、 各教科、道徳、特別活動及び総合的な学習の時間 のそれぞれの場面での環境教育の指導について述 ベられているが、環境教育の観点を持った教育活 動は、教科と総合的な学習の時間のそれぞれのね らいを有機的に結び付けることも期待できる。

近年、IEAのTIMSS（国際算数数学理科動向 調査) やOECDのPISA 学習到達度調査（国立教 育政策研究所 2004 など）などの国際比較調査の 結果から日本のゆとり教育の問題が指摘されるこ とも多い。国際間での成績順位が下がってきた という学力低下に関する課題より、「理科嫌い」、 「理科離れ」の問題がより深刻な場合がある。例 えば、小学校段階では理科が好きな児童が多いの に比べ、中学校・高等学校と学年が進行するにつ れて、理科嫌いが増えてくる。確かに数式に置き 換えたり、法則性を明確にしたりするなど、学習 過程で抽象的な思考力などの高次な取り組みが重 要視されるに従って、理科を嫌いになることも考 えられる。しかし、初等教育から中等教育への学 習者の発達段階を踏まえると、生徒は自然現象よ り人間関係に興味を持ち出すようになる。そのた め、自然科学を取り扱った場合、人間社会との関 わりを視野に入れる意義が認められる。理科に興 味があるため、その応用として環境に興味を持つ だけでなく、環境に興味を持ったため、理科にも 興味を持つという方向性も必要になると考える。 つまり、教科教育の中でも科学技術を社会的文脈 から捉えることが可能な視座を培う必要がある。

だが、自然と人間との関わりをどのように取り 扱うかは、個人や組織の価值観などとも関連して くる。その中で、地域は一つの意味を持つ。かつ
ての公害問題についての地域教材としての取り扱 いだけではない。地域における資源・エネルギー に関する問題、自然災害に対する防災・減災の問 題は環境教育の中でも重要な素材となることは何 度も繰り返して論じてきた(藤岡 2006)。しかし、 日本の学校教育の中では社会的に結論の出ていな い問題等を扱うことは避けられてきた。地域の切 実な課題として、学校教育の中でも発達に応じて 取り扱うことは今後ますます必要とされる。

また、先述した国際調査からのもう一つの課題 が明らかになっている。数学、理科の国際比較に ついては、TIMSS、PISA とも順位は下がったと は言え、上位グループに位置している。しかし、 OECDのPISA 学力到達度調査の結果において、 日本の生徒の読解力リテラシーでは、上位の国と 有意な開きがある（国立教育政策研究所 2004）。 そのため、読解力の強化が言われており、次期 学習指導要領でもこの点が重視される見込みであ る。しかし、この読解力の低さは必ずしも国語だ けの問題ではない。むしろ、理科でも無回答の割 合が高いところに問題が潜んでいる。つまり、込 み入ったことを論理的に自分の頭で考え、表現す るという過程を避けがちな傾向がある。これは、 従来の学習が受動的な姿勢を前提にして進められ てきたこととも大きな関係がある。そのため、環 境教育やESDで求められている主導的な能力や 態度の育成も不可欠となる。

このように環境教育を展開することで、他の教 科や教科外の教育活動の中で明確となっている現 在の教育課題に迫ることが可能となる。当然なが ら、環境教育やESDの意図を持った総合的な学 習の時間の活動においても、教科との関連性を無 視するわけにはいかない。その際、学習指導要領 では、それぞれの教科の学年ごとの目標が決まっ ているので、環境教育の展開としてもそれらを踏 まえたものである必要がある。

\section{3-2 総合的な学習の時間における教育方法の転換}

これまで述べてきた環境教育のねらいや目的を 考えた場合、学校教育における教育方法も大きく 変わってくる。つまり、総合的な学習の時間など での展開は、従来の教科学習などの一方通行的な 

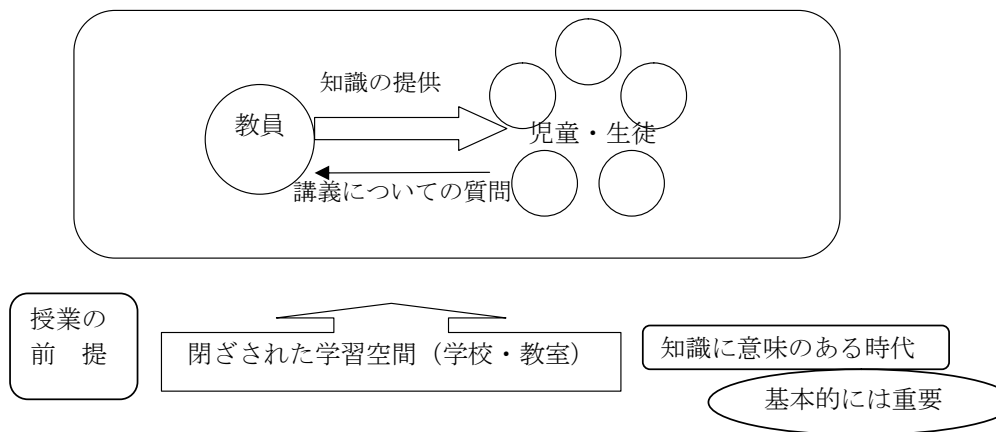

(1) 従来の学習モデル

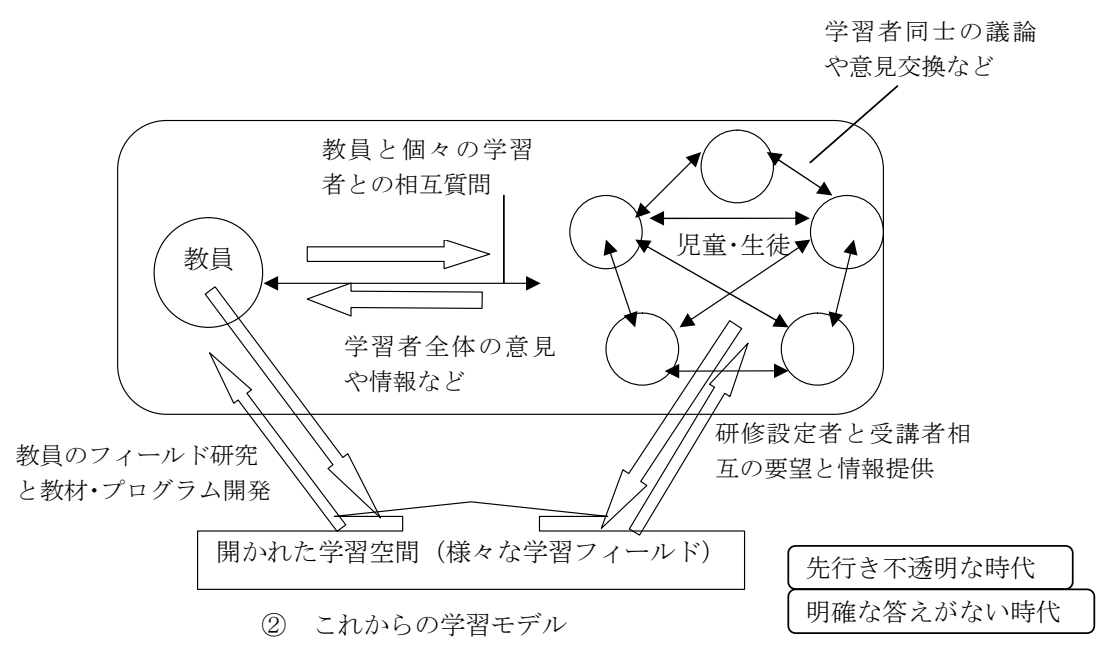

図 1 従来の教科を中心とした学習モデルとこれからの学習モデル（藤岡, 2004bを修正）

学びの形態だけでは、ねらいや目的を達成するた めに限界が認められる。ここで、従来の学びの形 態とこれから望まれる学びの形態の状況を図 1 に 模式的に示す。

図 1 - (1)に示したように、従来の学習のように 知識やスキルの習得を目的とした場合は、教員は 一方的な知識・スキルの伝達だけでもよかった。 ただ、現在でも教科学習などの基礎・基本的な学 習には、この形態は重要である。

しかし、知識の蓄積だけでは解決できない先行 き不透明な時代に対して、学習者のこれからの生 きる力を育成するには、この方法だけでは不十分 である。例えば、学習者同士のディスカッション など学習者の能動的な姿勢が不可欠となる。これ
にも様々な学習形態が考えられるが、その一例を 図 1 - (2)に示す。この場合、学習の場は閉鎖的な 教室だけにとどまらない（藤岡 2005）。

また、授業そのもののコンセプトも大きく変わ る。特に教員の役割自体が大きく変わり、教員も いわゆる学校の先生だけでなくなる場合もある。 従来の教科教育と総合的な学習の時間における観 点の比較を表 1 に示す。これらの学習形態や観点 は学校教育だけでなく、企業研修や教員研修の中 でも取り入られている（吉田 2006）。

\section{3-3 地域における環境教育展開の意義}

ここでは、「指導資料」（2007）に記されている、 「持続可能な社会の構築を目指す」、学校、家庭、 地域社会等と連携する」、「地域の実態から取り 
表 1 従来の教科学習と総合学習の授業展開の観点別比較

\begin{tabular}{|c|c|c|}
\hline 観 点 & 従来の教科学習の展開 & 総合学習の展開 \\
\hline 学びの単位 & 個人であることが多い & グループを単位とすることが多い \\
\hline 学びのスタイル & 知覚 (聴覚, 視覚) を用いる & 五感やからだ全体を用いる \\
\hline 教員の役割 & 講義者（知識・情報提供） & $\begin{array}{l}\text { 進行役, 知識 - 情報提供者 } \\
\text { 参加者, 体験演出者 }\end{array}$ \\
\hline 児童・生徒の役割 & $\begin{array}{l}\text { 聞く, 覚える } \\
\text { (受動的参加) }\end{array}$ & $\begin{array}{l}\text { 参加する, 影響し合う } \\
\text { 知識や技能を自らつくり出す（能動的参加） }\end{array}$ \\
\hline 教員の責任 & $\begin{array}{l}\text { 講義が中心になる } \\
\text { 知識やスキルの習得を目指す }\end{array}$ & $\begin{array}{l}\text { 相互の学びを可能にする環境をつくる } \\
\text { インパクトのある体験を演出する } \\
\text { 頻繁な振り返りを行いフォローアップもする } \\
\text { いい学びのモデル化を行う }\end{array}$ \\
\hline 学びの環境 & $\begin{array}{l}\text { 地位・身分が明かである } \\
\text { 真面目, 硬い印象を与える }\end{array}$ & $\begin{array}{l}\text { 柔らかい, 地位・身分が不明確な時もある } \\
\text { 楽しさ, ユーモアを備える }\end{array}$ \\
\hline 教員の関心事 & $\begin{array}{l}\text { 言いたいこと, 言うべきことを } \\
\text { 伝える }\end{array}$ & $\begin{array}{l}\text { 学習者が楽しく, かつ深く考えられるようにサポー } \\
\text { トする } \\
\text { 目的の共有と達成を協力して行う } \\
\text { 学びを手段として位置づけ, 絶えず, 次のステップ, } \\
\text { 広がりを考える }\end{array}$ \\
\hline 誰のニーズを満たすか & 教員 & 参加者, 進行役, その他 \\
\hline 学びがどれだけ役立つか & 少ないか, 不明 & ほとんどの参加者に役立つ \\
\hline
\end{tabular}

(J.Eitington 1989, 吉田 2006をもとに加筆)

組む」等の環境教育を行う際の主な視点を踏まえ て、地域において環境教育を実践する意義につい て論じたい。

日本の各地域では過疎化・高齢化・少子化など 教育環境をめぐっても様々な課題が存在する。地 域の振興や活性化にとっても次世代の人材の育成 は不可欠である。つまり、子ども達は地域の人達 から伝達すべき産業や文化遺産を継承されたり、 担い手となったりすることが期待されている。一 方、学校においても、総合的な学習の時間で強調 している生きる力の育成を目指した場合、様々な 課題があり、学校教育だけでは限界が見られるの も事実である。前節で述べたようなキャリア教育 を踏まえた体験活動や世代間交流などはその例で ある。そのため、地域が学校に期待し、教育活動 に協力をしたり、逆に学校が地域へ情報を発信し たりすることが多く見られる（藤岡他 2006）。こ れらの関係は地方において深さが見られるが、都
市部においても連携による活動の意義は同様であ り、この連携の中にNPOが関わることも多い。 これらの地域と学校との関係をまとめたものを図 2 に示す。これまでもこれらの活動には総合的な 学習の時間が活用されることが多かったが、2003 年の改訂された学習指導要領（文部科学省 2004） にも記載されているように、この時間を通じての 地域と学校との連携が期待される。

ここで重要なことは、地域は子ども達を保護し たり、人材を育成したりするだけではないという ことである。逆に、子ども達が地域の振興や活性 化に貢献することも見られる。例えば、2004年 中越地震の時には、総合的な学習の時間の中での 子ども達の活動が大人達にも復興への刺激を与え たことが報告されている。例えば、信濃川火焔街 道博学連携プロジェクトにおいて地震に遭ったと きでも子どもの熱意によって例年通りの活動が継 続されたこと（金子 2006）、また、避難所での子 


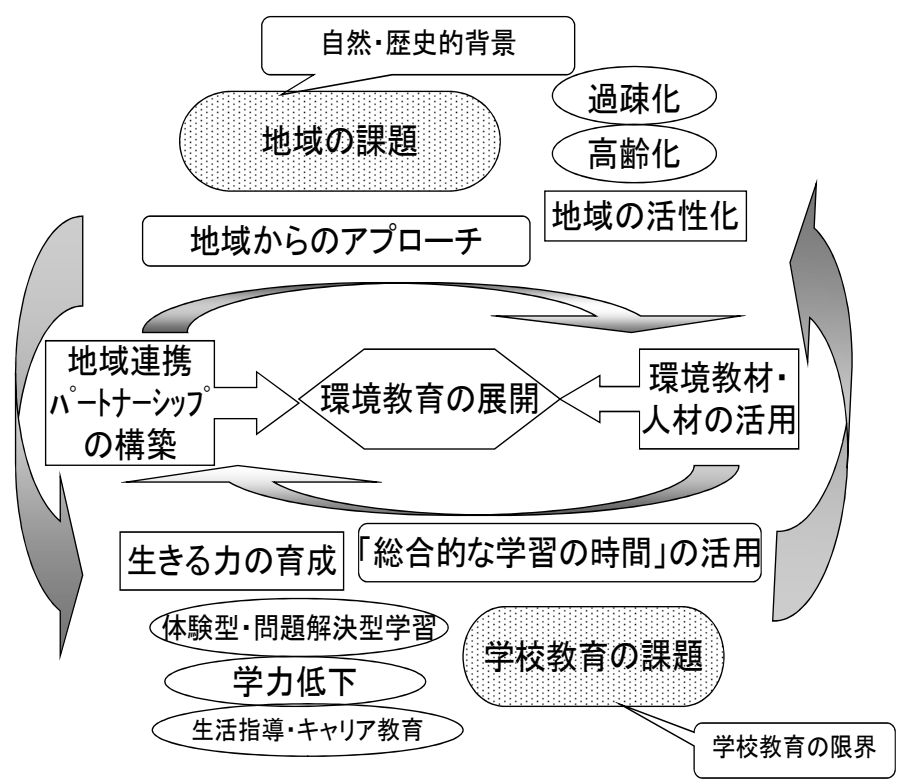

図2 環境教育を中心とした地域と学校との相互関係

ども達の清掃活動や合唱等が避難所の大人達に激 励となったこと等が地域への貢献として挙げられ る。

さらに地域の振興や活性化に子どもが関わる例 は多い。佐渡においても年々観光客が減少しつつ あり、観光を産業の基盤とする地域にとっては大 きなダメージを受けている。そこで、市内のいく つかの中学校では、観光ボランティアに取り組ん だり、観光客を対象とした祭りなどのイベントに 参加したりしている。これらの活動には、保護者 や地域の人達の支援も不可欠であるが、逆に大人 も子ども達への支援によって地域への自覚が向上 することが示されている。

このような活動が、「わが国における『国連持 続可能な開発のための教育の 10 年』実施計画」 の中の、「3． $\mathrm{ESD}$ 実施の指針（3）教育の内容」 として「地域づくりに参画する態度を育成するこ とが大切である。」(p.7) に繋がる実践と言える。 つまり、子どもの頃から地域の活動に参加するこ とによって、地域に対する危機意識や地域への愛 着、誇りにつながることが期待できる。

今日、学校教育についても地方と都市部とで
人々の意識に差があるのは事実である。生活空 間が異なるとそれらの理解は必ずしも容易ではな い。地方での高齢化・少子化等の問題、産業振興 の課題等が都市部では実感として理解できにくい ことも多い。そのため、総合的な学習の時間を通 じての地方からの発信も重要な意味がある。

\section{4 教員養成・教員研修における環境教育推進の ためのシステムの再構築}

環境教育の活動を実践するためには、教員の果 たす役割は非常に大きく、環境教育や ESDにつ いても教員の資質・能力の向上のためのシステム 構築、特に教員研修の整備は重要な意味をもつ。

「わが国における『国連持続可能な開発のため の教育の 10 年』実施計画」の中で、「 $4 . \operatorname{ESD} の$ 推進方策 (2) 国内に打ける具体的な推進方策 (二) 能力開発、人材育成」として、「学校教育の資質 向上のため、都道府県教育委員会等の指導主事等 を対象に、研修を行い、受講した指導主事等がこ れらの内容を踏まえた研修等を各地で行えるよう にする。（p.11）や、「大学の教職課程において、 ESDに関する内容を積極的に取り上げるととも 
に、実践的な指導方法が教授されるよう促す。」 （p.11）が記されている。これらの重要性は、こ の実施計画でも明確にされているが、具体的にど のような展開が必要であり、可能であるかは読み 取れない。

日本での教員研修の最も体系的・組織的なシス テムとしては、都道府県単位での教育委員会に 密接した教育センターでの研修がある。都道府県 レベルの教育センターでは、環境教育に関する研 修講座が開講されているところが多く、初任者研 修や十年目研修などの一環として悉皆研修の一部 で実施されているところも見られる。確かに教育 センターで開催される研修での環境教育とは何か についての講義では、それなりの定見はうかがえ る。ただ、環境教育のカリキュラムは画一的では なく、数回の講座だけで完結することは不可能で ある。各地域の特色に応じた環境教育が期待され るが、選定された講師に委ねられることが多い。 教員研修についても図 1 - (2)で示したような形態 が望まれるが、実態としては研修講師の一方的な 講演が多い（藤岡 2003）。

しかし、その教育センターにおける教員研修で さえ、従来どおりの研修講座数や時間数の確保 は、予算・スタッフの削減から年々厳しくなりつ つある。さらに担当するスタッフの育成等の問題 点もある。鳩貝（1999）は全国の教育センターで の環境教育の研修講座を担当するスタッフの調査 から、センターに着任して比較的短期間の人が多 いことを明確にしたが、環境教育研修担当者の新 たな能力・資質向上のための機会を設けることも 重要である。これは単にスタッフが環境教育の知 識をもつだけのいわゆるインストラクター的な能 力の向上だけではない。研修を企画・運営する上 でのコーディネー夕的な能力なども含まれる。

近年、教育委員会主催による研修講座でも NPO 市民団体、民間企業など教育関係者では ない人が講師を務めたり、学校以外などの場所 で研修を行ったりすることも多い。杉本・藤岡 （2004）は、NPOや環境教育に関するコンサルタ ントが講師を務める研修について、研修参加者の 意識調査から従来の指導主事や学校教員が講師を
務めるのとは違った意味があることを明らかにし ている。また、直接環境教育をテーマとした研 修でない民間企業体験研修においても、企業の環 境に配慮した取り組みに触れることによって、参 加者の環境に対する意識が深化することを藤岡 （2004a）は示している。これらは、いずれも教育 委員会がコーディネートした教員研修である。つ まり、教員研修においても、先に述べた学校と地 域との連携が必要であるのと同様に、教育委員会 や教育センターが様々な機関とパートナーシップ を構築することが望まれる。

また、海外での環境教育に関する教員研修を参 考にする意味がある。日本の教育研修の在り方と して、独立行政法人教員研修センターが全国の教 員や指導主事等を対象として実施している教員研 修に加え、都道府県レベルでの教育委員会・教育 センターが主導する点で、アメリカの環境教育研 修のシステムとは大きく異なっている。

例えば、プロジェクトワイルドやプロジェクト アドベンチャーなど、民間の団体が独自のテキス トを用いて、教員研修を常時行っているところな どと比較して、環境教育のどのような理念に焦点 を当て、どのような具体的な素材を取り扱うかと いう点でも大きな差違が明らかになる。当然、日 本のように全国画一的な学習指導要領にもとづい た検定済みの教科書が用いられているのとは違 い、州ごとのスタンダードに基づいて採択される という教育課程実施上の違いが背景にある。地域 の環境にもとづいた教材の作成や教員研修につい ては、日本でも今後、このような視点が不可欠で ある。

つまり、様々な教員研修に対応しきれなくなっ ている状況では、環境教育のようにテーマが広 範に存在している研究を進めるにあたって、教育 委員会も他の組織や人材と連携していく必要があ る。また、行政や地域がどのようにNPOや環境 教育コンサルタントを育成していくかの観点も課 題である。

加えて、教員養成の現状として、大学の中でも 必ずしも組織的に地域や学校を支援する方法が構 築されていないところが大部分である。教員養成 
を主に担っている教育大学や教育学部では、どれ だけ環境教育に関するカリキュラムが存在するの か疑問な点もある。環境教育の科目が開設されて いる教員養成系の大学は多いとは言えない。これ らは、教育大学においても環境教育の専門家がい ないこととも関わっている。教科教育と同様に、 環境教育の研究者を養成、育成することは教育大 学の今後の課題の一つである。

\section{5 まとめと今後の課題}

学校教育を中心としたこれからの環境教育の展 開についての展望と課題を「総合的な学習の時 間」を主題として論じてきた。

その中で環境教育や ESDの必要性は、これか らの日本の教育、場合によっては地域の将来とも 大きく関わっていることを示唆した。環境教育の 課題は、現代の学校教育の課題と無関係でない。 特に環境教育を学校教育の中で展開することに よって、従来とは学習方法やシステムが変わって くることが挙げられる。つまり、学習者の姿勢と して、知識・スキルの習得という受動的な学習か ら能動的な学習への態度の切り替えが生じる。戦 後から、日本の教育は体験学習型と系統学習型の 間を振り子のように動いてきたと言われるが、現 在の学校教育において、教員は、「学力」か「ゆ とり」か、「指導」か「支援」かなどのような単 純な選択をしているわけではない。

また、従来、学習の場は学校が主体であった が、学校外の場や学校外の人材が子どもの教育に も関わってきていることも大きな特色である。し かし、これらのコーディネート的な機能は学校に 託されている。つまり、社会的・家庭的な教育機 能が学校に委ねられてきている。一方で地域の活 性化や振興に学校が関わることも可能である。特 に、過疎化・少子化が進む地域において、学校の 存在意義がある。環境教育の推進は、日本の地域 の課題への解決のとっかかりや他地域の理解を通 じて、国際的な貢献までにも繋がることが期待で きる。

地域の環境教育の中で何を取り扱うかは地域に 委ねられることが多い。しかし、そこにも課題は
存在する。例えば、自然災害に関する防災や減災、 開発と保全などのトレードオフの中で、どのよう な社会の構築を目指そうとするのか、そのために どのような人材を育成すべきであるかの意思決定 や合意形成は必ずしも容易なことではない。この ような点でも具体的な方策が各地域から発信され ることが不可欠である。

自然環境や地域社会との関連性を重視した日本 独自の教育方法や内容への取り組みに小学校段階 から参加する姿勢を養う意味がある。地域への参 画主体として、子どもを見直す必要性である。環 境教育を理解するには多様な価值観が存在する社 会に目を向ける必要がある。同時に地方と都市と の交流、具体的には地方で生活することによっ て、日本の問題が見えてくることもあるだろう。 さらには、日本以外での国での体験のようなこと も重要である。

これらの対応で、学校や教員の役割はますます 大きく、複雑になりつつある。そのためのシス テムの構築が現在、各地域で模索中であると言え る。特に教員養成や教員研修の在り方についても 再構築の必要性に迫られている。

本稿では、触れることができなかったが、小学 校・中学校・高等学校の連続性も無視できない。 「環境教育指導資料 (小学校編)」は刊行された。 しかし、これに続く中学校、高等学校と環境教育 のねらいの連続性はどうなるかも大きな課題であ る。学校に委ねられた環境教育の取り扱いは必ず しも容易なことではない。しかし、学校が地域で の存在の大きさを確認すべき時であると言っても 過言ではない。地域の現状と課題を踏まえて環境 教育やESD と取り組むことは、今後の避けては 通れない日本の大きな課題である。

\section{文献}

藤岡達也, 2003, 科学教育に関連した教員研修に おける教育センターと一般行政・企業・大学の 連携一大阪府を例にした都道府県レベルの教育 センターの今日的な役割とその課題一, 科学教 育研究, $27,1,50-59$.

藤岡達也, $2004 \mathrm{a}$, 現職教員への科学 - 技術 - 社 
会相互関連理解の機会としての民間企業体験研 修についてー教育現場・民間企業・教育委員会 の連携による研修から-, 科学教育研究, 28 , 1 , 67-78.

藤岡達也, 2004b, サイエンス・パートナーシッ プ・プログラム事業における教員野外研修につ いてー研修機関と研究者との新たな連携構築の 観点から-, 地学教育, 57, 6, 203-216.

藤岡達也, 2005, 地学教育の観点からとらえた自 然災害時におけるボランティア活動および教育 大学の役割について - 平成 16 年 $\lceil 7.13$ 新潟水 害」を事例としてー, 地学教育, 58, 5, 157-163. 藤岡達也, 2006, 自然災害に関する防災・減災教 育と環境教育, 環境教育, $16,1,32-38$.

藤岡達也 · 戸田智 - 石田浩久, 2006, 学校 - 博物 館を取り込んだ地域連携による景観の活用につ いてー信濃川中流域における火㷈型土器出土の 縄文遺跡に関した連携から一, 歴史地理, 48,1 , 35-44.

鳩貝太郎, 1999, 教育センター等における現職 教員の環境教育指導向上についてのプログラ 厶開発, 平成 $8 \sim 10$ 年度科学研究費報告書, 1-144, 東京.

金子和宏, 2006, 「縄文」をキーワードに博学 連携プロジェクトー新潟県中越地震をも乗り 越え広域の博学連携プロジェクトを推進一, 125-130, 藤岡達也編著「地域環境教育を主題 とした総合学習の展開」, 協同出版, 191, 東京. 「国連持続可能な開発のための教育の 10 年」関係 省庁連絡会議，2006，わが国における「国連持 続可能な開発のための教育の 10 年」実施計画, 同連絡会議, 東京.

国立教育政策研究所編，2004，生きるための知識 と技能 OECD生徒の学習到達度調查（PISA） 2003 年調査国際結果報告書, 375, ぎょうせい,
東京.

国立教育政策研究所教育課程研究センター, 2007,

環境教育指導資料 (小学校編), 107, 国立教育 政策研究所, 東京.

文部科学省, 2004, 小学校学習指導要領平成 10

年 12 月告示平成 15 年 12 月一部改正, 国立印刷 局, 105 , 東京.

文部科学省, 2001, 学校教育法の一部を改正する 法律案の概要, http://www.mext.go.jp/b_ menu/houdou/13/03/010312.htm, 2001.3.13.

文部科学省, 2003, 初等中等教育における当面の 教育課程及び指導の充実・改善方策について

(答申), http://www.mext.go.jp/b_menu/ shingi/chukyo/chukyo0/toushin/ 03100701. htm, 2003.10.7.

文部科学省, 2004 , 平成 16 年度公立小.中学校 における教育課程の編成実施状況調査, http:// www.mext.go.jp/b_menu/shingi/chukyo/ chukyo3/siryo/004/06080916/010/013/002. htm, 2007.11.14.

文部科学省, 2007, 新しい学習指導要領, http:// www.mext.go.jp/a_menu/shotou/new-cs/ link/index.htm, 2007.11.14.

文部省, 2002, 環境教育指導資料 (小学校編), 119 , 大蔵省印刷局, 東京.

大阪府, 2002, 体験的環境学習推進事業報告書,

52 , 大阪府農林水産部, 大阪.

杉本史生・藤岡達也, 2004, 環境教育をテーマと

した教員研修を担う環境 $\mathrm{NPO}$ 等の条件につい てー大阪府の環境学習人材支援事業を事例とし て - , 環境教育, 13，2，55-62.

吉田新一郎, 2006, 効果 10 倍の<教える技術> 授業から教員研修まで, 230, PHP 新書, 東京. Etington. Julius.E., 1989, The Winning Trainer, 824, Gulf Publishing, Texas, USA. 